December 2019

\title{
SRJ: Leading the Genre-Defying LIS Profession
}

Greta Snyder

snyder.greta@gmail.com

Follow this and additional works at: https://scholarworks.sjsu.edu/ischoolsrj

Part of the Archival Science Commons, Cataloging and Metadata Commons, Collection Development and Management Commons, Information Literacy Commons, Museum Studies Commons, Scholarly Communication Commons, and the Scholarly Publishing Commons

\section{Acknowledgements}

Snyder would like to thank previous Editor-in-Chief Megan Price for her passion and vision, Managing Editor Rachel Greggs for her integrity and wit, and Dr. Anthony Bernier for his humor and insight, and the entire SRJ Editorial Team for their dedication and the SJSU iSchool Faculty Advisory Board for demonstrating the value of research and supporting SRJ's bold endeavor.

\section{Recommended Citation}

Snyder, G. (2019). SRJ: Leading the Genre-Defying LIS Profession. School of Information Student Research Journal, 9(2). https://doi.org/10.31979/2575-2499.090201 Retrieved from https://scholarworks.sjsu.edu/ischoolsrj/vol9/iss2/1

This article is brought to you by the open access Journals at SJSU ScholarWorks. It has been accepted for inclusion in School of Information Student Research Journal by an authorized administrator of SJSU ScholarWorks. For more information, please contact scholarworks@sjsu.edu. 


\section{SRJ: Leading the Genre-Defying LIS Profession}

\section{Keywords}

editorial, diversity, equity, access, LIS, professional development, libraries, archives, information, culture, graduate research, research, editors

\section{Acknowledgements}

Snyder would like to thank previous Editor-in-Chief Megan Price for her passion and vision, Managing Editor Rachel Greggs for her integrity and wit, and Dr. Anthony Bernier for his humor and insight, and the entire SRJ Editorial Team for their dedication and the SJSU iSchool Faculty Advisory Board for demonstrating the value of research and supporting SRJ's bold endeavor.

\section{About Author}

Greta Snyder is honored to be the current SRJ Editor-in-Chief though Spring 2020. Snyder writes the SJSU iSchool Career Blog and is passionate about student outreach, professional development and the value of research to improve professional practice. Snyder graduates this Fall 2019 from SJSU iSchool with her MLIS and looks forward to launching her LIS career. 


\section{SRJ Leading the Genre-Defying LIS Profession}

The Library and Information Science profession continues to present an infinite variety of places and ways to practice. The possibilities might be endless, but the values and principles we take into the field must be constantly evaluated, defined and debated. What better way to interrogate our core assumptions and the current demands than through rigorous scholarship and relevant research? Being able to align your values with your professional practice and articulate resources and research to give veracity and traction to your strategic objectives and future directions will make you a better LIS professional. Per the 2019 SJSU iSchool "MLIS Skills at Work Report: A Snapshot of Job Postings Spring 2019," 68\% of jobs seek communication skills and $22 \%$ specifically cite research skills as required--making the value of $S R J$, the only fully graduate-student run, doubleblind peer-reviewed academic journal focusing on publishing graduate student research in the LIS field all the more palatable. A commitment to life-long learning and the personal pursuit of professional development emerge as crucial keys to success in the constantly evolving LIS profession. So, do not fall behind, read our 19th issue: stay curious and keep asking how you can expand the concept of LIS as a profession and the impact you make every day.

We are thrilled to publish an invited contribution from Dr. Deborah Hicks, SJSU iSchool Assistant Professor, that provides a sneak-peak at her prescient research into an emerging and crucial LIS topic: "Debating Diversity; How Twitter Facilitates Professional Discussions." Hicks, recently awarded a grant for research into this crucial arena of discourse on the nature and influence of Twitter in the context of the LIS field, shares some compelling questions the research will address. Hicks' contribution discusses the potential of Twitter as a professional tool for increasing inclusion and embracing diversity in the LIS field. Speaking to the profession's values of diversity and intellectual freedom, Hicks identifyies the need for professional organizations to articulate these professional values within the context of emerging forms of online communication and community-building tools, such as Twitter. Hicks' research will contextualize and tease out core debates within the LIS profession regarding Twitter as a platform and how to align professional values with social media engagement. Hicks' work could not be any more on point with key questions in our field and professional community and it is a true pleasure to share a preview.

Author Ali N. Sadik-Ogli's evidence summary reviews a pioneering 2018 study focusing on the circulation and collection of zines from the perspective of zine authors themselves. This study addresses the value of inclusive circulation and collection that incorporates a broader perspective of types of records and content, such as born-digital, self-produced and limited-edition physical productions. In the increasingly virtual and fluid world of artistic and culture production, expanding our vision as LIS professionals of how to increase equity of access while ensuring proper attribution and means for supporting creators is a delicate balance worthy of exploration.

Author Lisa Lowdermilk's compelling article examines the understudied fiction writing information community. Lowdermilk's synthesis of literature on 
the topic indicates that networking between writers and sharing archives of fictional writing would enrich the information resources for building community through a shared understanding of the creative process and therefore empower a community of current and future storytellers.

Does the concept of genealogical plagiarism interest you? Me too. Author Katherine Richers' article exploring ethical concerns in genealogical records emerges to address a very prescient topic in the context of an era of emerging mechanisms of big data, artificial intelligence, and increasingly digital health records. Richers raises the question of how the LIS field can be proactive in establishing standards for awareness and education on the topic in order to ensure increased access while upholding the integrity of information and the value of sharing records with the intention to make the past accurately visible through the presence of ethical record keeping.

Author Michelle Leasure analyzes the value of game-based learning as an innovative pedagogical technique in the academic library setting. Leasure specifically looks at the University of Alabama Libraries' Project Velius and Barlow's indie video game Her Story, which unintentionally created a perfect blueprint for a narrative-driven, completely immersive library instruction tool. In an era where college students are increasingly "digital natives," Leasure's article suggests crucial future directions for libraries to integrate game-based learning into information literacy programming and instruction to increase inclusion and accessibility.

Public libraries are increasingly stepping up as community advocates for public health and social service resource centers. Author Heather Elia's article draws attention to the history of public libraries supporting the physical, mental, and social health of their patrons and deep dives into an analysis of the role public libraries currently play in public health and community wellness. Elia's look at the role of public libraries and library professional organizations in addressing the recent opioid crisis adds to the dynamic discourse on such a crucial LIS topic for professional practice.

Author Emily Mercer's article focuses on the ethics of recordkeeping and archiving for non-profit organizations (NPOs) whose primary missions revolve around civil and human rights, education, the environment, animal protection, or human services. Mercer argues that if these NPOs seek LIS professionals to develop mission-aligned record keeping and sharing strategies this will improve the current and future impact and effectiveness of these NPOs. Mercer's ability to identify emerging ways for LIS professionals to make a positive impact and effectively expand beyond traditional spheres makes this a must read.

Mercer's article takes us home by tying together the themes of this issue: best practices in the increasingly cross-discipline, genre-defying LIS field for cultivating diversity, inclusion, equity of access, and community building, and accounting for emerging and digital forms of media and records in archival work, collection management and in professional communication with a constant look to the future while preserving the past with integrity. The breadth of graduate student and practicing professional research included in this issue demonstrate that $S R J$ remains committed to escape velocity by publishing innovative research 
and asking crucial forward-thinking questions to forward the LIS field and our professional practice every day. SRJ's passion for pushing the boundaries of how our chosen genre-defying profession can amplify our impact through intellectual exploration and research and sharing and leads us with 2020 vision into our $10^{\text {th }}$ anniversary in 2021. We look forward to celebrating with you, our readers and supporters, and encourage graduate students to submit original research, literature reviews, book reviews, critical essays and evidence summaries. Our anniversary milestone will not be complete without you.

\section{Acknowledgements}

I could not end this editorial without waxing poetically about what a superb privilege it has been working with the SRJ's undercover hero, Managing Editor Rachel Greggs. Greggs' truly remarkable aplomb, grace, sense of humor, and editing abilities truly made this issue's quality content milestone possible: with six graduate student submissions published we have now shattered the glass ceiling. I credit this achievement to Greggs' exceptional leadership and our entire editorial team's thoughtful and constructive review and feedback to authors. We are truly lucky to have so much talent, passion and dedication on our side; thank you to our phenomenal editors Channon Arabit, Claire Goldstein, Esther Momand, Phyllis Pistorino, Terry Schiavone, and Havilah Steinman.

Dr. Anthony Bernier, our fearless Faculty Advisor, joins Greggs on the $S R J$ podium of unsung heroes. Bernier's dedication to furthering student scholarship and professional practice in the LIS field is truly visionary. No amount of celebratory emojis could account for Bernier's positive influence on student development through SJSU iSchool and in the MLIS program. I remain eternally grateful for Bernier's insight and guidance in journal outreach efforts, student-centered approach and focus on the future for the LIS profession.

A final profound thank you the Editorial Board, led by iSchool Director Dr. Sandra Hirsh and Associate Director Dr. Linda Main, and to all the faculty and staff at the iSchool that grant our team such professional insight into cultivating graduate scholarship and crucial LIS research at the SJSU iSchool. Our team remains committed to the values of our advisory board who see the opportunities, possibilities, and power of an LIS career and the significance of contributing to research in the field to further our professional practice.

\section{References}

"MLIS Skills at Work Report: A Snapshot of Job Postings Spring 2019." (2019). SJSU iSchool.

Retrieved from https://ischool.sjsu.edu/sites/main/files/fileattachments/career_trends.pdf?1559581197 